\title{
Edamame (green soy beans) biliary stones
}

\author{
Hiroki Iriyama, ${ }^{1}$ Mikiro Kato, ${ }^{1}$ Masao Nogami, ${ }^{1}$ Yasuharu Tokuda ${ }^{2}$
}

${ }^{1}$ Mito Kyodo General Hospital, Mito, Japan

${ }^{2}$ Japan Community Healthcare Organization, Tokyo, Japan

\section{Correspondence to}

Dr Mikiro Kato,

k.mikiro@gmail.com

Accepted 3 October 2014
CrossMark

To cite: Iriyama $\mathrm{H}$, Kato $\mathrm{M}$, Nogami $\mathrm{M}$, et al. BMJ Case Rep Published online: [please include Day Month Year] doi:10.1136/bcr-2014207677

\section{DESCRIPTION}

We present the case of an 89-year-old tiny woman who presented with a 2-day history of fever. Her medical history included gallbladder stones, hypertension, osteoporosis, rheumatoid arthritis and dementia. Vital signs showed an elevated temperature of $38.3^{\circ} \mathrm{C}$ and tachypnoea. She was frail with a body weight of $28 \mathrm{~kg}$. There was no abnormality on the abdominal examination. However, abdominal CT scan showed dilation of common bile duct with numerous large-sized stones (figure 1) mimicking 'edamame' (figure 2). ${ }^{1}$

For diagnosis of acute cholangitis associated with common bile duct stones, antibiotics were initiated and endoscopic stone removal was conducted with a complication of retroperitoneal perforation, which was treated conservatively; placement of metal biliary stent was conducted secondarily. After the procedure the patient made a good clinical course and she was eventually discharged home. ${ }^{2}$

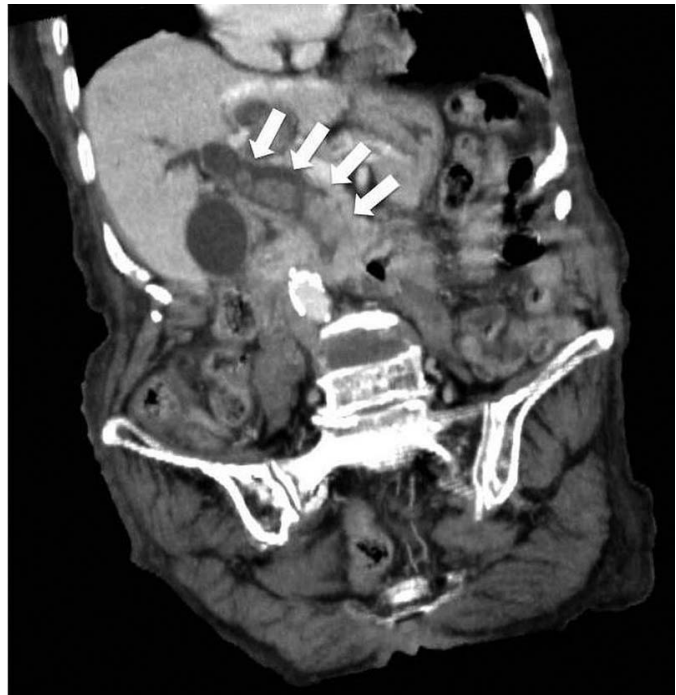

Figure 1 Coronal image of abdominal CT scan showing dilation of common bile duct with numerous large-sized stones (white arrows) mimicking 'edamame'.

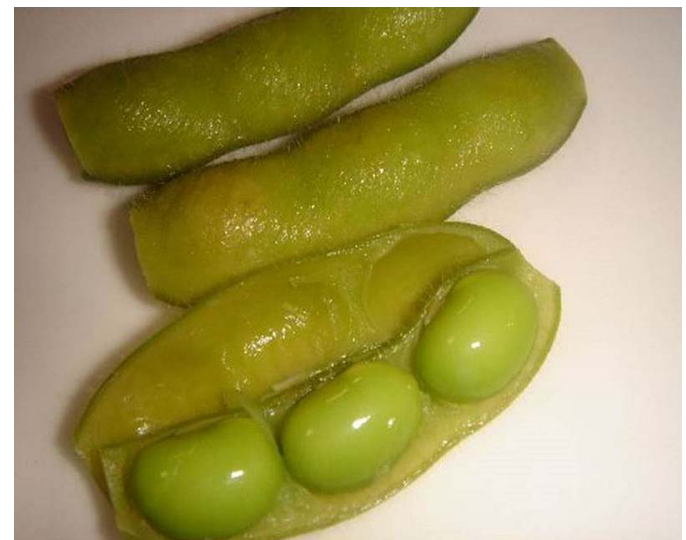

Figure 2 'Edamame' (green soy beans).

\section{Learning points}

- Elderly patients with gallbladder stones may develop multiple common bile duct stones masquerading as 'edamame'.

- Multiple common bile duct stones are a common cause for acute cholangitis which may not be associated with abnormality of abdominal examination.

- Endoscopic management is also effective for the treatment of multiple common bile duct stones even in extremely elderly patients.

\section{Competing interests None.}

Patient consent Obtained.

Provenance and peer review Not commissioned; externally peer reviewed.

\section{REFERENCES}

1 Maple JT, Ben-Menachem T, Anderson MA, et al; ASGE Standards of Practice Committee. The role of endoscopy in the evaluation of suspected choledocholithiasis. Gastrointest Endosc 2010;71:1.

2 Katsinelos P, Paroutoglou G, Kountouras J, et al. Efficacy and safety of therapeutic ERCP in patients 90 years of age and older. Gastrointest Endosc 2006;63:417-23.

Copyright 2014 BMJ Publishing Group. All rights reserved. For permission to reuse any of this content visit http://group.bmj.com/group/rights-licensing/permissions.

BMJ Case Report Fellows may re-use this article for personal use and teaching without any further permission.

Become a Fellow of BMJ Case Reports today and you can

- Submit as many cases as you like

- Enjoy fast sympathetic peer review and rapid publication of accepted articles

- Access all the published articles

- Re-use any of the published material for personal use and teaching without further permission

For information on Institutional Fellowships contact consortiasales@bmjgroup.com

Visit casereports.bmj.com for more articles like this and to become a Fellow 